\title{
Origin and secondary alteration of coalbed and adjacent rock gases in the Zonguldak Basin, western Black Sea Turkey
}

\author{
HAKAN HOŞGÖRMEZ \\ Istanbul University, Engineering Faculty, Geology Department, TR-34320, Avc1lar, Istanbul, Turkey
}

(Received March 3, 2006; Accepted March 23, 2007)

\begin{abstract}
Investigation of molecular and carbon isotopic composition variability of hydrocarbon gases (methane, ethane and propane) has been performed on gases from coal and rock samples from Kozlu district of the Zonguldak Basin in order to ascertain the origin of gases and to explain possible reasons of variations in molecular and isotopic composition. For this purpose, the molecular and isotopic composition of eight headspace and associated gases from coals and adjacent organic rich sediments of two different stratigraphic levels of Kozlu formation in the Zonguldak basin have been determined. Total organic carbon (TOC) measurements and Rock-Eval pyrolysis were performed in order to determine bulk organic geochemical characteristics of the respective intervals.

Coal and associated rock samples contain predominantly vitrinite rich type III organic matter with hydrogen indices (HI) up to $162 \mathrm{mgHC} / \mathrm{gTOC}$. The stable carbon isotope ratios $\left(\delta^{13} \mathrm{C}\right)$ of the kerogen vary from $-25.52 \%$ to $-28.05 \%$. All the headspace gaseous hydrocarbons are dominated by methane $(>94 \%)$. $\delta^{13} \mathrm{C}$ range for methane, ethane and propane of the headspace samples are defined as; $\delta^{13} \mathrm{C}_{1}:-48.4 \%$ to $-36.3 \%$ o, $\delta^{13} \mathrm{C}_{2}:-26.7 \%$ to $-17.5 \%$ and $\delta^{13} \mathrm{C}_{3}:-31.8 \%$ o to $-22.3 \%$, respectively. Methane isotopic composition and molecular ratios of the gases show that the origin of gases is mainly thermogenic. But admixture of some biogenic gas is also possible. The amount of the biogenic admixture is controlled mainly by cleat/fracture intensity of the coal or rock. The biogenic admixture of methane increases with increasing intensity of the rock fractures. In other words, methane isotope composition becomes much lighter with increasing proximity to a fault of to a crushed zone. Isotopic composition of methane and geological history of the basin led to the conclusion, that biogenic component is related with secondary bacterial gas generation.

Ethane is unexpectedly heavier than the propane in all of the analyzed samples. It becomes heavier in samples particularly from the Mileopera seam, which is intensively cleated. The gases with a negative stable carbon isotope sequence of $\delta^{13} \mathrm{C}_{2}>\delta^{13} \mathrm{C}_{3}$ may possibly imply a microbial alteration. Respective isotope values of headspace and associated gases can also be influenced additionally by desorption process, which is caused by uplift of the basin during the last 42 million years.
\end{abstract}

Keywords: coal-bed gas, isotopic composition, secondary bacterial gas, microbial oxidation, western Black Sea

\section{INTRODUCTION}

The coal-bearing Carboniferous sequence of the Zonguldak Basin is located in Northwestern Turkey on the Black Sea Coast (Fig. 1). The Zonguldak Basin consists of Carboniferous coal seams which are produced since more than 100 years. Consequently, the basin was studied by several researchers for different reasons: geology (Kerey, 1982), coalbed methane potential (Mann et al., 1995; Yalçın, 1995, 1997; Yalçın et al., 1994, 2002; Harput et al., 1999), source rock potential (Derman and İztan, 1997), organic petrography (Karayiğit, 1989; Karayiğit et al., 1998), adsorption capacity of coals (Gürdal and Yalçın, 1995; Gürdal, 1998; Gürdal and

*e-mail address: hosgorme@istanbul.edu.tr

Copyright (c) 2007 by The Geochemical Society of Japan.
Yalçın, 2000), amount and molecular composition of coalbed gas in various coal seams (Hoşgörmez, 1996; Hoşgörmez et al., 1997, 1998).

Until now, detailed investigations on isotopic composition of coalbed gas in the Carboniferous Zonguldak Basin coals are limited. The only one study is carried out by Hoşgörmez et al. (2002) on the headspace samples from two boreholes (AK-14 and AK-16) in the Amasra region of the Zonguldak Basin. This study, showed that isotopically light methane and to a certain degree ethane and propane can be related to of an admixture of thermogenic and secondary biogenic gas.

The objectives of this study are to determine the molecular and isotopic composition of coalbed and adjacent rock gases in the Kozlu district of the Zonguldak basin and to discuss its origin. Furthermore, it is aimed to figure out whether cleat/fracture intensity of coals does influence the molecular and isotopic composition of the 


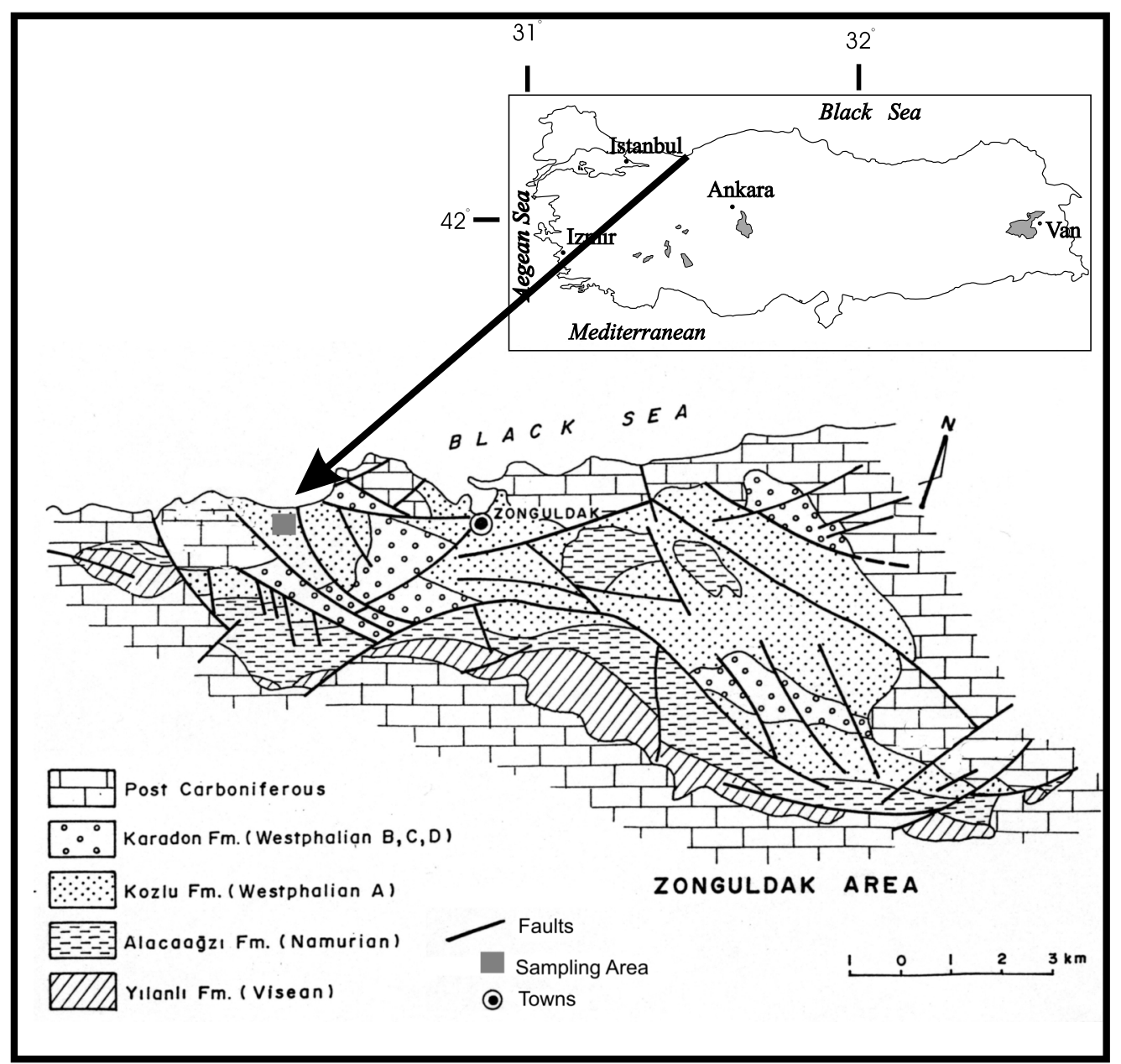

Fig. 1. Location map of the Kozlu Block (Zonguldak), showing the geological map of the study area and coal operation area in Zonguldak Basin.

gases. For this purpose, headspace samples were taken from different coal seams of varying cleat intensity and from localities of varying fracture intensity caused by faults. Data obtained from the analyses are used to classify the gases, to distinguish their origin and to discuss possible effects of seconday processes on molecular composition and isotope ratios.

\section{STRatigraphy OF THE CoAl SEAMS}

The oldest unit of the coal bearing sequence of the Zonguldak Basin Carboniferous is the Visean aged Yilanlı Formation, which consists of marly and partly dolomitic limestones and carbonaceous shales (Fig. 2). Y1lanlı Formation is conformably overlain by Alacaağzı Formation. Namurian-aged Alacaağzı Formation consists predominantly of light-colored fine to medium-grained, crossbedded sandstones and siltstones interbedded with shale (Yergök et al., 1987; Orhan and Canca, 1989).
Alacaağzı Formation is conformably overlain by Kozlu Formation which contains of mostly coal seams. Westphalian-A aged Kozlu Formation is formed by interbedded sandstones, siltstones, mudstones, conglomerates and coals. The overlying Westphalian B-C aged Karadon Formation bears a similar succession as the Kozlu formation, however with less number of coal seams. They exist more than twenty coal seams such as Mileopera, Çay, and Acılık within the Kozlu formation. Net coal thickness for this stratigraphic sequence ranges from 30 to 32 $\mathrm{m}$ across the Kozlu region.

The Carboniferous Alacaağzı, Kozlu and Karadon Formations are unconformably overlain by Cretaceous units (Fig. 2) (Görür and Tüysüz, 1997; Yılmaz et al., 1997), which generally composed of limestone and dolomitic limestone. The Carboniferous units experienced two major burial and subsequent uplift-erosion episodes. These two episodes of burial and subsequent uplift and erosion are typical for the entire region and have remark- 


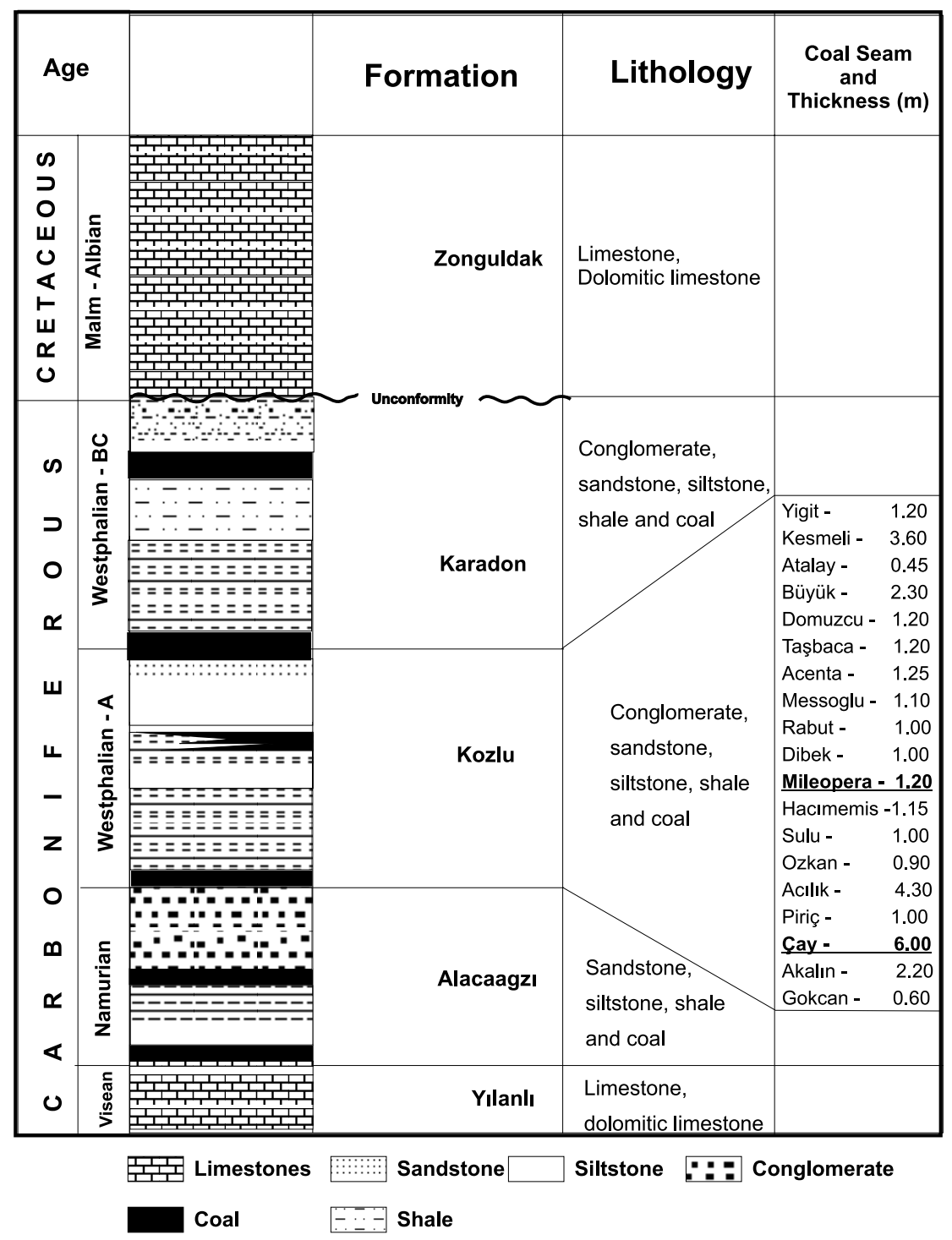

Fig. 2. Generalized stratigraphic section of the study area from the Zonguldak Basin.

ably controlled the coalification, gas generation, desorption of coal-bed gas within the Carboniferous coals (Yalçın et al., 2002).

Active tectonics during the Paleozoic and Mesozoic in the Western Black Sea region had a major control on structural evolution of the basin. East-Northeast/Westsouthwest striking folds and thrusts with a northerly vergence indicating West-Northwest/East-Southeast compression has occurred a as a result of the Hercynian orogeny. The next major tectonism is represented by EastWest striking normal faults in connection with a rift system during the Albian-Cenomanian (Görür et al., 1993; Robinson et al., 1996). Consequently, these faults caused fracturing of coal beds and formed suitable pathways for meteoric water flow.

\section{SAMPLES AND METHODS}

Samples were taken from coal seams and adjacent rocks present the Kozlu Formation in the Kozlu Coal District, Zonguldak (Fig. 1) at eight different points using headspace cans. During sampling, after the blasting in the gallery, aliquots, which were taken from a piece of rocks of 4-5 cm thick from fresh rock surfaces, were immediately placed in air-tight glass containers. Tap water was then added until a sufficient space at the top of the containers was left for the accumulation of the socalled "headspace gas". The samples were preserved in sealed headspace cans (Schaefer et al., 1984). Bacterial degradation was inhibited by adding benzalkonium chloride $\left(\right.$ Zephirol $\left.^{\circledR}\right)$. Four of the samples were collected from 


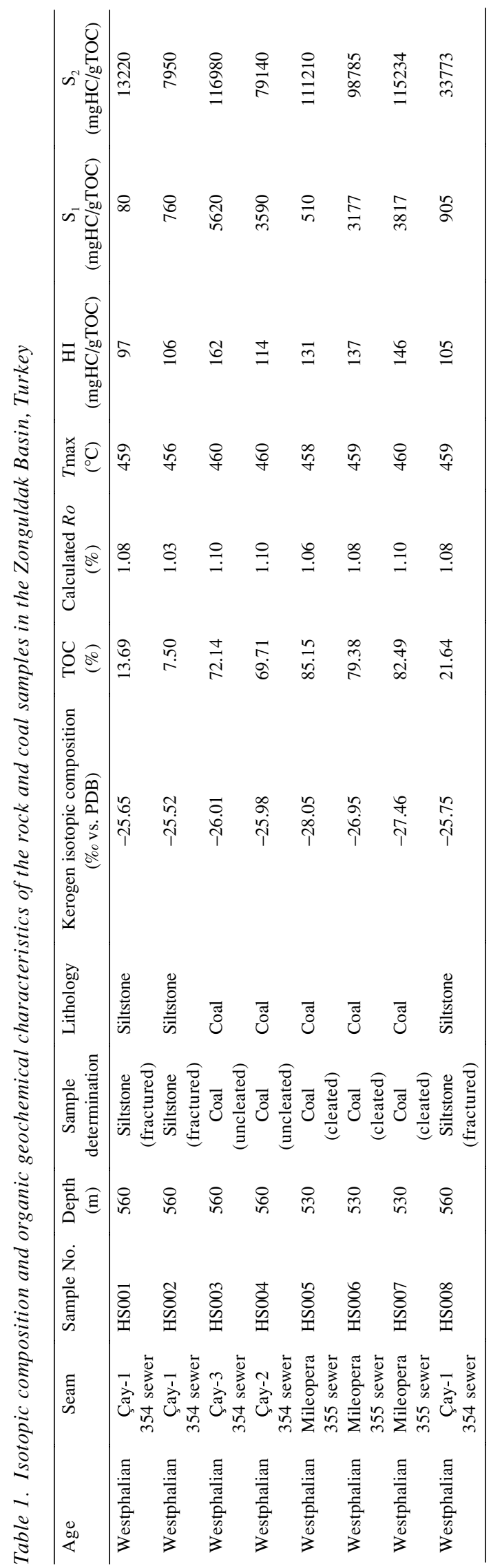

a 560 meter deep collier and the rest were collected from a 530 meter deep collier. Sampling from multiple localities and lithologies which have different structural properties can provide better understanding of the factors on gas isotope composition. For this purpose, sample were selected from two coal seams of the Kozlu formation: Mileopera and Çay. Although, a few samples were taken from faulted and fragmented localities, some of them were collected from unfractured coal seams. Structural properties such as fracture of the coal seams were determined by visual impressions. Fractured coal means coal seams with well developed cleats that additionally fractured by tectonics. Properties of the Mileopera samples (HS005, HS006, and HS007) are commonly incompact and have an advanced ground water circulation, although Çay samples are more compacted and have less ground water circulation outside the fault zones. Determination of the fracture effects on gas isotopes was an important part of this study. Thus, Çay seam was sampled in a systematic manner that samples were taken starting from the fault zone toward the unfractured parts of the coal seams. Çay samples were classified into the two groups: Fractured siltstones-Çay (HS001, HS002, HS008) and unfractured coals-Çay (HS003, HS004) samples on the basis of their cleat intensity.

According to visual impressions of the rock surfaces in the cave, water circulation increases with increasing fracture intensity. Ground water spills out from the fracture/fault surfaces toward the cave. Three ground water samples were collected from fractured/faulted zones of Mileopera and Çay seams for the determination of water chemistry (Table 4). Alkalinity is measured by titrating a water sample with an acid to an endpoint $\mathrm{pH}$ about 7.9. The amount of oxygen dissolved in water is measured by a oximeter (WTW oximeter 330) as a concentration, in milligrams per liter $(\mathrm{mg} / \mathrm{l})$ of water.

The analysis of the amount and composition of gases was carried out on "headspace gas" at STP conditions after two months. The headspace and associated gas measurements of the coal samples were carried out by Agilent$6890 \mathrm{~N}$ gas chromatograph, equipped with a (FID)-(TCD) detector, to determine type of hydrocarbons, their molecular composition and amount of $\mathrm{CO}_{2}$ and $\mathrm{N}_{2}$ gases in samples. Gases were separated on TCD detector by means of a GC, equipped with a HP-Plot/Q (30 m; $0.542 \mathrm{~mm}$; $40.00 \mu \mathrm{m})$ and HP-molesieve $(30 \mathrm{~m} ; 0.539 \mathrm{~mm} ; 50.00$ $\mu \mathrm{m})$ column. Hydrocarbon gases were deeply devised by a FID detector with HP-AL/S (50 m; $0.534 \mathrm{~mm} ; 15.00$ $\mu \mathrm{m})$ column. The measurement results were evaluated by GC Chemstation software.

For the determination of molecular composition of the gases, a correction was carried out in order to eliminate admixtures of air. Air correction was calculated from the equation $\mathrm{N}_{2 \text { corrected }}=\mathrm{N}_{2 \text { measured }}-\left(\mathrm{O}_{2 \text { measured }} \times 3.7\right)$. In case 
of bacterial oxidation, the oxygen concentration of sample is changed after consumption. Thus, the calculation precision can be affected by bacterial oxidation process. The nitrogen amounts are normalized according to the typical nitrogen content of same rank-coals (Table 2).

When the headspace gas analyses were finished, associated gas samples were prepared to determine the amount and composition of the trapped gases in the pores and sorbed gases on coal surface of the samples. Associated gases were defined trapped gases in pores of the rocks were stimulated at the $85^{\circ} \mathrm{C}$ (Busch, 1995).

Stable isotope analyses of gases were performed using a GV-IsoPrism High Performance instruments with continuous flow GC-IR-mass spectrometer at TÜBITAK Marmara Research Center. Analytical precision was $\pm 0.3 \%$ o for methane and $\pm 0.5 \%$ o for higher components $\left(\mathrm{C}_{2}\right.$ and $\left.\mathrm{C}_{3}\right)$. The isotopic results are reported in $\delta^{13} \mathrm{C}$ notation in parts per mil (\%o), relative to the Peedee Belemnite (PDB) standard.

Rock Eval pyrolysis and total organic carbon measurements were performed in order to determine source rock properties (e.g., amount, type and $T \max$ ). The vitrinite reflectance values were calculated from the equation proposed by Hoşgörmez (1996) (Table 1).

$$
R o(\%)=\frac{T \max -388.978}{64.8307}
$$

where: Tmax represents the temperature corresponding to the maximum of hydrocarbon generation during pyrolysis. The $R o(\%)$ values were accordingly calculated, using the $T \max$ of the measured samples on the equation (Table 1).

\section{Organic Geochemical Properties of CoAls AND GaSes}

Coal seams and siltstones within Kozlu formation have total organic content amounts of 7.5 to $85.2 \%$. Rock-Eval pyrolysis data of coals indicate that the organic matter is predominantly vitrinite rich-Type III kerogen (Fig. 3). The average $\delta^{13} \mathrm{C}$ values of kerogen of the samples are between -28.05 and $-25.52 \%$. The $\delta^{13} \mathrm{C}_{\text {kerogen }}$ values of Mileopera and Çay coal seams range from -28.1 and $-26.0 \%$ and display significant ${ }^{12} \mathrm{C}$ enrichment with increasing hydrogen index (Table 3 ). The samples of Mileopera coals have different $\delta^{13} \mathrm{C}_{\text {kerogen }}$ values, between -28.05 and $-26.95 \%$. Above all, this ${ }^{12} \mathrm{C}$ enrichment at the Mileopera coals is attributed to a relatively higher hydrogen index. The average $\delta^{13} \mathrm{C}$ values of siltstone samples are rather uniform, between -25.75 and $-25.52 \%$.

The percentage of hydrocarbon gases $\left(\mathrm{C}_{1}-\mathrm{C}_{5}\right)$ present in headspace samples ranges from $98.3-99.0 \%$. The headspace samples consist predominantly of methane with

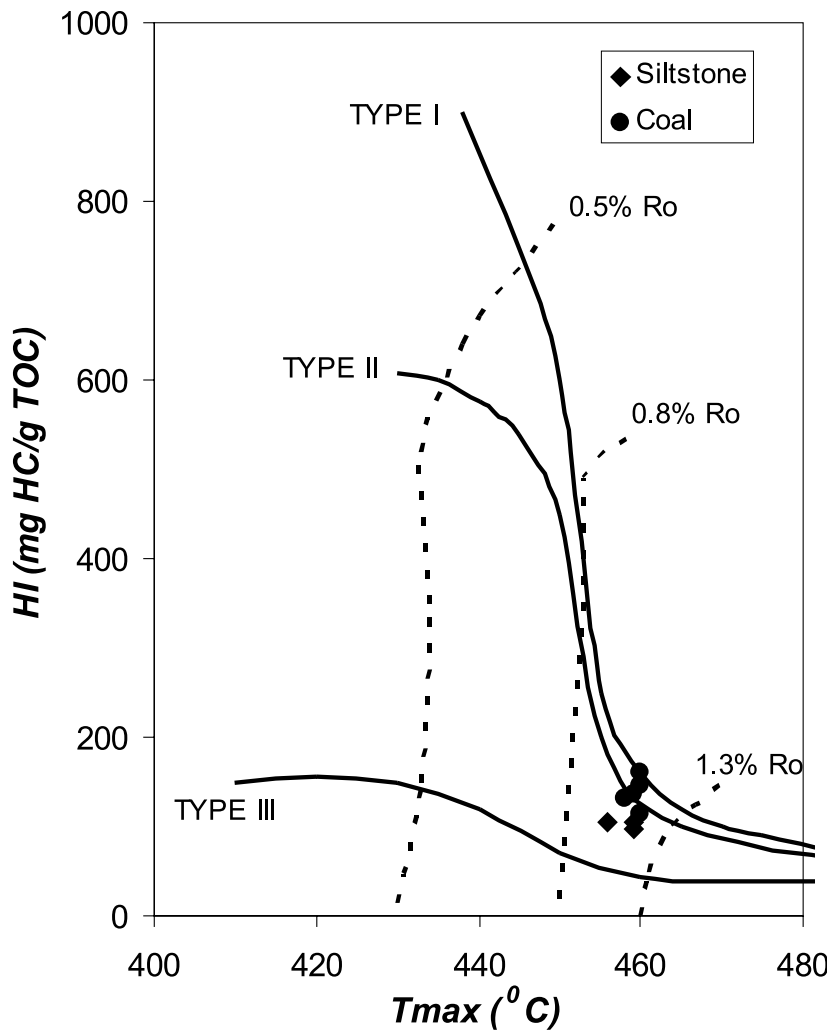

Fig. 3. Hydrogen index (HI) versus Tmax diagram of analysed samples.

minor amount of $\mathrm{C}_{2+}$ gases; methane ranges between 94.06 to $98.45 \%$ of total HC-gases (Table 2). The remaining hydrocarbon gases are dominantly ethane and propane percentage of the total $\mathrm{C}_{2+}$ gases is generally lower than $4.26 \%$. In addition to hydrocarbon gases, $\mathrm{CO}_{2}$ and $\mathrm{N}_{2}$ are also present. The $\mathrm{CO}_{2}$ content of the gases varies from $0.01 \%$ to $0.7 \%$ (Table 2). The nitrogen amount was normalized based on the average nitrogen content within coal gases (\%1), since its amount could not determined correctly.

While $\delta^{13} \mathrm{C}$ values of methane, ethane and propane of headspace gases range between -48.4 to $-36.3 \%$ o, -26.7 to $-17.5 \%$ and -31.8 to $-22.3 \%$, respectively (Table 2 ), those of associated gases range between -47.6 to $-35.5 \%$, -25.7 to $-17.3 \%$ and -29.4 to- $21.2 \%$, respectively (Table 3). The isotope composition of the headspace and associated gas samples are similar and do not represent remarkable difference.

\section{ORIGIN AND ALTERATION OF GASES}

The classification diagram suggested by Bernard et al. (1978) is used to investigate the origin of gases. For this purpose, the $\mathrm{C}_{1} /\left(\mathrm{C}_{2}+\mathrm{C}_{3}\right)$ ratio versus the $\delta^{13} \mathrm{C}$ values of methane compound is taken into consideration (Fig. 


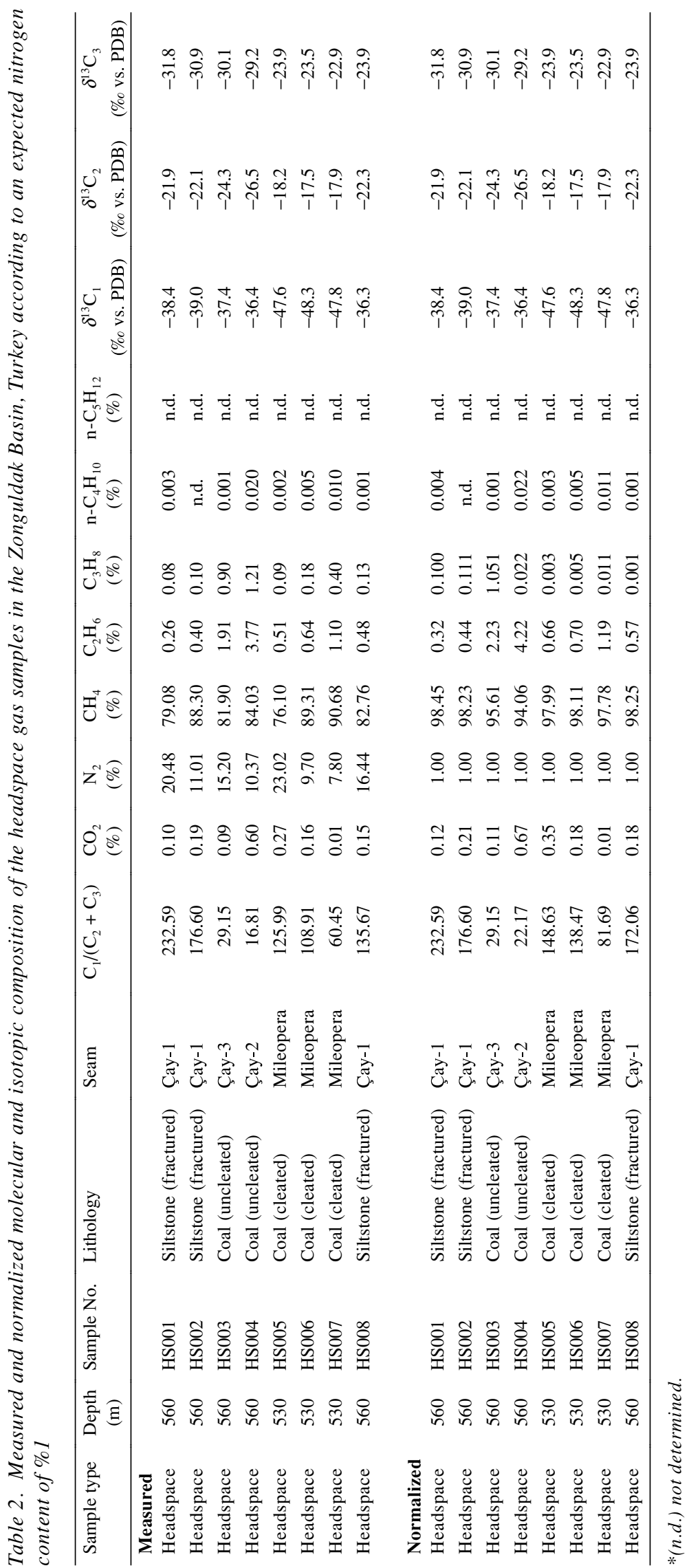


Table 3. Molecular and isotopic composition of the associated gas samples in the Zonguldak Basin, Turkey

\begin{tabular}{|c|c|c|c|c|c|c|c|c|c|}
\hline Sample type & Sample No. & $\begin{array}{l}\text { Depth } \\
(\mathrm{m})\end{array}$ & Lithology & Seam & $\begin{array}{l}\mathrm{CH}_{4} \\
(\%) \\
\end{array}$ & $\begin{array}{c}\mathrm{C}_{2} \mathrm{H}_{6}-\mathrm{C}_{5} \mathrm{H}_{12} \\
(\%)\end{array}$ & $\begin{array}{c}\delta^{13} \mathrm{C}_{1} \\
\text { (\%o vs. PDB) }\end{array}$ & $\begin{array}{c}\delta^{13} \mathrm{C}_{2} \\
\text { (\%o vs. PDB) }\end{array}$ & $\begin{array}{c}\delta^{13} \mathrm{C}_{3} \\
(\% \text { vs. PDB) }\end{array}$ \\
\hline Associated Gas & ASS001 & 560 & Siltstone (fractured) & Çay-1 & 97.84 & 2.16 & -39.2 & -22.6 & -30.0 \\
\hline Associated Gas & ASS002 & 560 & Siltstone (fractured) & Çay-1 & 97.87 & 2.13 & -37.3 & -22.3 & -29.4 \\
\hline Associated Gas & ASS003 & 560 & Coal (uncleated) & Çay-3 & 92.82 & 7.18 & -36.7 & -23.5 & -29.4 \\
\hline Associated Gas & ASS004 & 560 & Coal (uncleated) & Çay-2 & 93.79 & 6.21 & -36.5 & -25.8 & -27.8 \\
\hline Associated Gas & ASS005 & 530 & Coal (cleated) & Mileopera & 97.49 & 2.51 & -46.4 & -18.6 & -23.5 \\
\hline Associated Gas & ASS006 & 530 & Coal (cleated) & Mileopera & 99.01 & 0.99 & -47.2 & -17.6 & -22.5 \\
\hline Associated Gas & ASS007 & 530 & Coal (cleated) & Mileopera & 98.45 & 1.55 & -47.6 & -17.3 & -21.9 \\
\hline Associated Gas & ASS008 & 560 & Siltstone (fractured) & Çay-1 & 96.48 & 3.52 & -35.2 & -23.5 & -24.2 \\
\hline
\end{tabular}

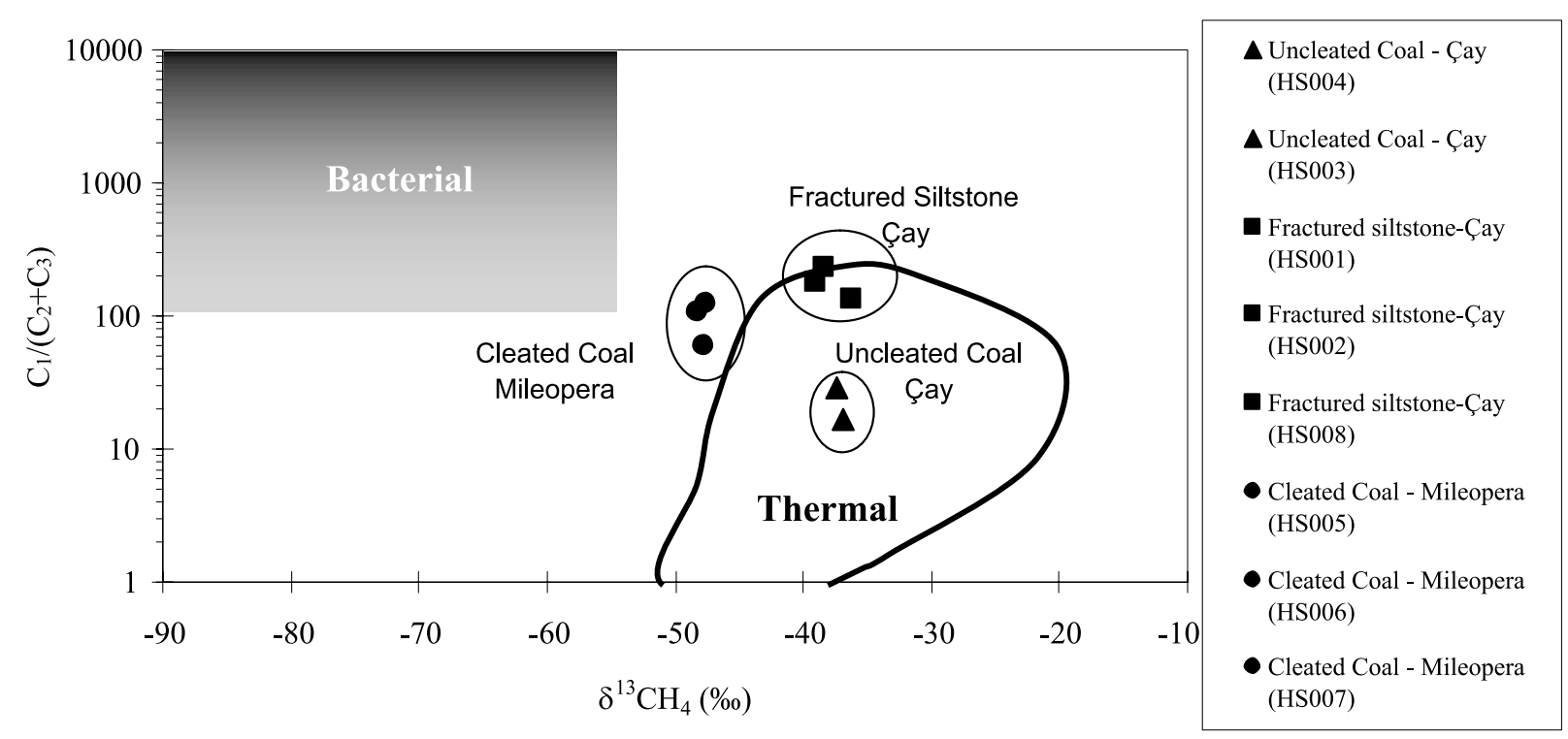

Fig. 4. Genetic characterization of gas occurrences in Carboniferous coals in Zonguldak Basin according to molecular ratio $\left(C_{1} / C_{2}+C_{3}\right)$ versus $\delta^{13} C$ isotopic composition of methane after Bernard et al. (1978).

4). According to this diagram methane from the investigated Carboniferous coal seams and siltstones are formed, partly by a mixture of thermogenic and microbial methane and partly by a pure thermogenic source. Whereas samples from unfractured parties of uncleated Çay seam (HS003, HS004) plot within the zone of thermogenic origin, rest of the samples (HS001, HS002, HS005, HS006, HS007, HS008) plot in a transitional zone between thermogenic and bacterial origin. The cleated coal samples from Mileopera seam (HS005, HS006, HS007) have rather a lighter isotopic composition $\left(\delta^{13} \mathrm{C}_{1}-48.3\right.$ to $-47.5 \%$ ), which suggests a higher microbial gas contribution (Fig. 4). The classification diagram indicates that molecular and isotope composition of gases is affected by secondary processes such as bacterial admixture. In order to figure out how the investigated gases have been affected by secondary processes, a comparison of the measured iso- topic compositions with that of a pure thermogenic gas generated from a similar source rock is conducted.

For this purpose, carbon isotope values of methane, ethane and propane of a gas, thermally generated from a Type III source rock $\left(\delta^{13} \mathrm{C}_{\text {kerogen }}-26.0 \%\right.$ ) at a maturity of 1.0 to $1.2 \mathrm{Ro} \%$, have been determined with the help of the modeling approach proposed by Berner and Faber (1996). The modelled data show that the $\delta^{13} \mathrm{C}$ values of methane, ethane and propane range between -30.6 to $29.9 \%$, -26.3 to $-25.7 \%$ and -24.1 to $-23.7 \%$, respectively. Comparison of these calculated values with the values of Carboniferous coal seam gases in this study showed that methane is much lighter, whereas ethane carbon isotopes are unexpectedly heavier (Fig. 5).

The stable carbon isotopes of cleated Mileopera seam gases (HS005, HS006, and HS007) show that $\delta^{13} \mathrm{C}$ values of methane are remarkably lighter but ethane and pro- 


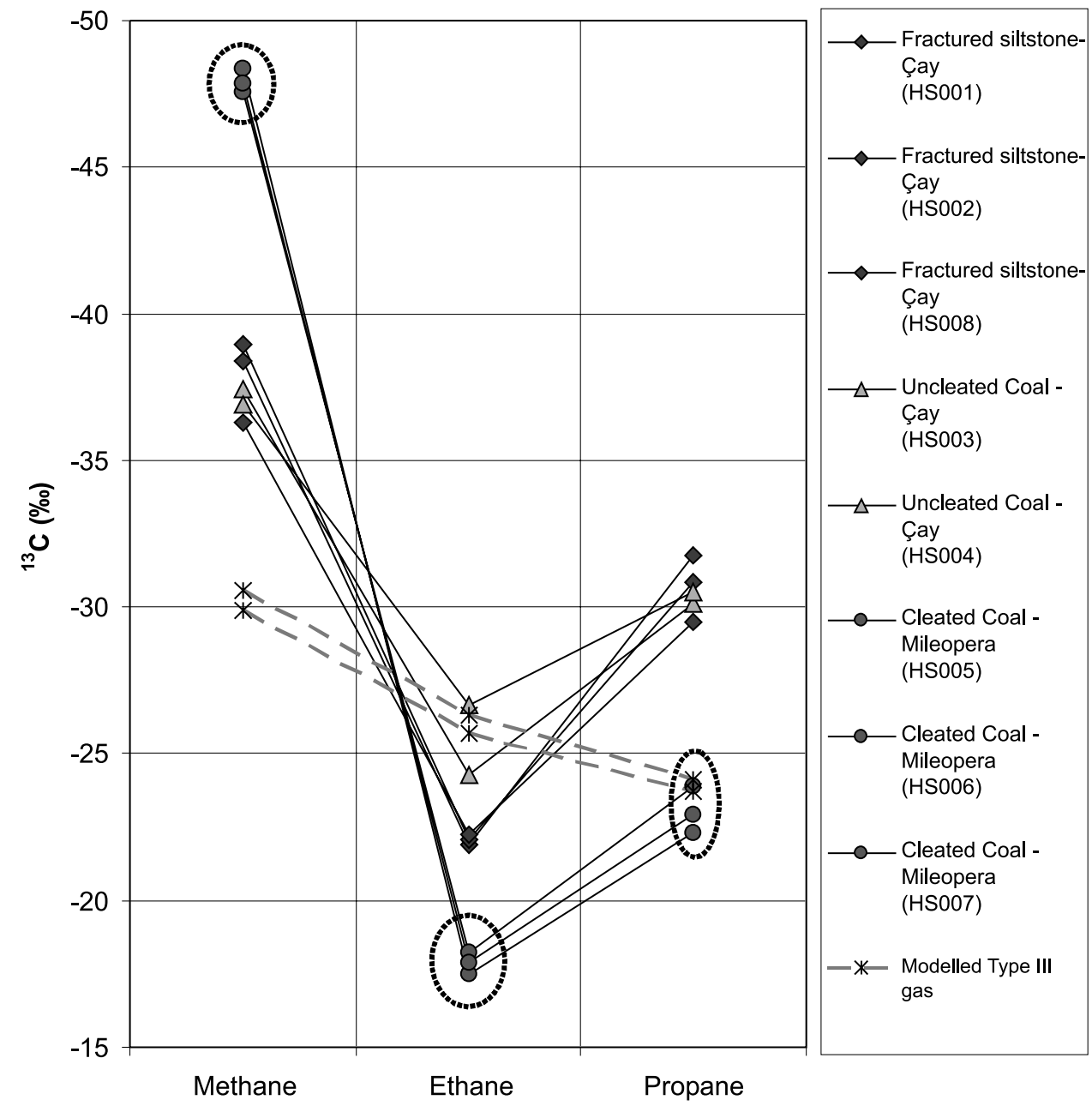

Fig. 5. Modelled type III gas line data proposed by Berner and Faber (1996) is generated from typical Type III organic matter ranging from 1.0 to $1.2 \mathrm{Ro} \%\left(\delta^{13} C_{\text {kerogen }}-26.0 \%\right.$ ) for the comparison of the measured values of the study area. The stable carbon isotopes of coal seam gases show that $\delta^{13} C$ values of methane becomes lighter but ethane and propane carbon isotopes become heavier.

pane carbon isotopes are remarkably heavier than other gases (Fig. 5). Methane from uncleated Çay samples that are taken far away from the fault zone has the lowest amount of biogenic gas and ethane shows only slight indications for a secondary alteration (Fig. 5). In general methane appears to have been admixtured with an isotopically lighter microbial gas, but the partial reversal in the stable carbon isotopes of the heavier ethane suggests probably a secondary effect (Fig. 5).

The origin of the lighter methane isotopes can be explained by a secondary biogenic gas generation as suggested by Scott (1993), Scott et al. (1994) for San Juan Basin and by Hoşgörmez et al. (2002) for the Amasra district of the Zonguldak Basin. Methane carbon isotopes show that a remarkable relationship exits between the secondary biogenic gas generation and density of cleats/ fractures and respectively enhanced ground water circu- lation. The quantity of the sodium chloride $(\mathrm{NaCl})$ amount of the fracture water is ranges from $0.008-0.016 \%$. Dissolved oxygen amount of the fracture water varies from 6.3-6.9 mg/lt (Table 4). Sodium chloride and dissolved oxygen amounts caused that show that water in the fractures is fresh and of meteoric origin. The meteoric water caused that living bacteria are introduced into permeable coalbeds.

Ethane carbon isotopes are however heavier than propane in all samples e.g., the isotopic composition ethane and propane compounds of the investigated gases exhibits a reversible with respect to regular gases in the light of the expected positive stable carbon isotope sequence of $\delta^{13} \mathrm{C}_{2}<\delta^{13} \mathrm{C}_{3}$. This unusual isotopic composition may be explained by a bacterial oxidation and/or desorption. Bacterial oxidation is commonly encountered in several reservoirs and coalbed gas fields (Scott, 1993; Scott et 
Table 4. Chemistry of water in the coal seams in the Zonguldak Basin, Turkey

\begin{tabular}{llcllccc}
\hline Sample type & Sample No. & $\begin{array}{c}\text { Depth } \\
(\mathrm{m})\end{array}$ & Lithology & Seam & $\begin{array}{c}\mathrm{NaCl} \\
(\%)\end{array}$ & Ph & $\begin{array}{c}\text { Dissolved oxygen } \\
(\mathrm{mg} / \mathrm{lt})\end{array}$ \\
\hline Water & $\mathrm{W}-1$ & 530 & Coal (cleated) & Mileopera & 0.008 & 7.81 & 6.3 \\
Water & $\mathrm{W}-2$ & 560 & Siltstone (fractured) & Çay-1 & 0.010 & 8.77 & 6.9 \\
Water & $\mathrm{W}-3$ & 560 & Coal (uncleated) & Çay-3 & 0.017 & 7.25 & 6.3 \\
\hline
\end{tabular}

al., 1994). Oxidation of hydrocarbons most likely occurs by microbial alteration. The bacteria oxidize and use preferentially ${ }^{12} \mathrm{C}$ of $\mathrm{CH}_{4}$ (Barker and Fritz, 1981). In such a case, the remnant gas is depleted in ${ }^{12} \mathrm{C}$. James and Burns (1984) showed that the ethane alteration is not as strong as the propane in the subsurface oil reservoirs. They suggested that the bacterial alteration of the gases resulted in depletion of the amount of $\mathrm{C}_{3}-\mathrm{C}_{5}$ hydrocarbons. Based on their observations, propane appears to be selectively attacked during the initial stages of bacterial alteration. This implies that the propane isotopic composition tends to be heavier. In contrary, Clayton et al. (1997) and Pallaser (2000) reported the most positive $\delta^{13}$ values of ethane as a consequence of its microbial alteration together with relatively unaltered $\delta^{13}$ values of propane. Xu et al. (1997) observed that the carbon isotopic composition of ethane and $n$-butane are influenced by the microbial activity. Thielemann et al. (2004) also mentioned the oxidation of the ethane and propane compounds in a coalbed gases. Under suitable conditions straight-chain hydrocarbons are influenced from microbial oxidation and this causes ${ }^{13} \mathrm{C}$ enrichment in the remaining gases. Therefore, the isotopic compositions of the remnant $\mathrm{C}_{2+}$ compounds are shifted to positive values. Ethane within the Zonguldak basin coal bed gas is much more depleted. Therefore the isotopic tendency toward positive values of ethane might be due to the microbial oxidation.

Organic matter surfaces adsorb the gases due to physical attraction by van der Waals and electrostatic forces (Faiz et al., 2002; Yee et al., 1993). Adsorption capacity is controlled by pressure, temperature, geometries and electrical properties of gas molecules and pore sizes (Cui et al., 2004). According to Langmuir's theory, sorption capacity increases with increasing molecular weight of a sorbed gas species. Hence, propane will be adsorbed preferentially and strongly than ethane and methane. The uplift caused by the Alpine orogeny resulted in an erosion of approximately $2000 \mathrm{~m}$ during the last 42 million years in the Zonguldak Basin (Yalçın et al., 2002; Hoşgörmez et al., 2002). Hence, the uplift gave rise to desorption due to decreasing pressures of about 200 bars (Yalçın et al., 2002). Several authors have reported an isotopic shift towards positive values of methane, ethane and propane caused by desorption of coalbed gas (Gould et al., 1987; Xu et al., 1997; Sassen et al., 2004; Thielemann et al.,
2004; Mahieu et al., 2006; Strapoc et al., 2006). Magnitude of isotopic fractionation in methane by desorption is given as $\sim 2 \%$ (Strapoc et al., 2006). Experimentally, the isotopic shift during desorption within 14 months for ethane and propane in coals were obtained as +1.3 to $+2.8 \%$ and +0.5 to $+3.8 \%$, respectively (Thielemann $e t$ al., 2004). Consequently, desorption process can also be considered as one of the reasons of the heavier ethane. The difference in isotopic compositions of ethane and propane varies between $-9.9 \%$ and $-4.8 \%$. These differences are much higher than the desorption effects mentioned above. Therefore, only desorption can not explain the negative stable carbon isotope sequence of $\delta^{13} \mathrm{C}_{2}>$ $\delta^{13} \mathrm{C}_{3}$.

The molecular composition of hydrocarbon gases indicated, that they are thermogenic which is consistent with the thermal maturity levels of the coal. However, according to the isotopic composition of methane some of the coal gases are secondary biogenic in origin, generated bacterially. Consequently, almost the entire coalbed gas is represented by a mixture of thermogenic and secondary biogenic gas. In contrast, the ethane from the coal seams is rich in heavier carbon isotope signature indicating that the isotopic composition value of ethane probably results from selective uptake of ethane and propane by unknown group of microorganisms.

\section{CONCLusions}

Coals and siltstones gases of Westphalian-A aged Kozlu formation at the Kozlu district represents a mixture of thermogenic and secondary biogenic gas. The thermogenic component, mainly composed of hydrocarbon gases, is generated from humic coals and/or from a source rock bearing vitrinite rich Type III kerogen. The biogenic component is formed as secondary biogenic gas, indicated by isotopically light methane as end product. This process is caused by bacteria, which attack the existing heavier hydrocarbons and lead to biogenic methane generation. This mechanism is confirmed by the fact, that methane from cleated/fractured coals and from intervals with a higher cleat/fracture density is isotopically much lighter than methane from less cleated/fractured or unfractured coals. The enhanced water circulation within cleated/fractured coals connected with faults to the surface is the most 
probable agent which brings the bacteria to subsurface. The isotopically heavier ethane encountered within the coalbed gas represents a controversial aspect, since the secondary bacterial gas generation actually should result in also lighter ethane. This unusual appearance can be explained also by bacterial activity, where bacteria preferentially oxidize and use ${ }^{12} \mathrm{C}$ isotopes. As a consequent, the remnant gas is depleted in ${ }^{12} \mathrm{C}$, e.g., enriched by ${ }^{13} \mathrm{C}$, which causes a shift of isotopic composition towards heavier values. When bacteria consume ethane and propane compound to generate biogenic methane, the first consumed ethane and propane will be isotopically lighter and only the isotopically heavier will be left behind. Furthermore, desorption which was initiated by the uplift of the coal seams during the last 42 million years may also have led to an enrichment of ${ }^{13} \mathrm{C}$, as ${ }^{12} \mathrm{C}$ rich compounds are more mobile then ${ }^{13} \mathrm{C}$-compounds. Hence, both bacterial oxidation and desorption can be considered for the reason of unusually heavy ethane, which is also observed in some other coal basins (Thielemann et al., 2004; Dai et al., 2005; Zou et al., 2006). It is inferred that isotopically lighter ethane formed by secondary bacterial gas generation is overwhelmed by heavier ethane, formed by bacterial oxidation and desorption processes. Existence of heavy propane can also be explained by the bacterial oxidation. In addition, the changes of isotope composition of ethane are related to hydrogen index of the organic matter, suggesting that higher hydrogen index of the organic matter have been consumed preferably by bacteria because of their attractiveness.

The sequential order of different type gas generation and alteration is explained in the following under the consideration of geologic evolution. During Late Carboniferous a primary bacterial gas generation took place, when deposition of coaly units took place. After that as a result of coalification a thermogenic gas generation from coaly organic matter of the Kozlu formation and accumulation of this gas within the coal beds occurred. According to the basin modeling results of Yalçın et al. (1994) and Yalçın (1997), this happened between 90 to 42 million years before present (mybp). Towards the end of this period, at the deepest part of the Kozlu formation a late gas generation took place. Due to the latest tectonic uplift, meteoric water with bacteria introduced into the deeper subsurface and secondary bacterial gas generation and oxidation was initiated (Hoşgörmez et al., 2002).

Acknowledgments-Prof. Dr. M. Namık Yalçın is thanked for valuable comments which markedly improved the manuscript. The author would like to thank to two anonymous reviewers for their helpful suggestions, which helped to improve the manuscript remarkably. Water chemistry analyses by Dr. Semih Sezer, Esra Ilhan Sungur and Nihal Doğruöz, are gratefully acknowledged. The author thanks Mr. Özcan Öney for his sampling help.

\section{REFERENCES}

Barker, J. F. and Fritz, P. (1981) Carbon isotopic fractionation during microbial methane oxidation. Nature 293, 289-291.

Bernard, B. B., Brooks, J. M. and Sackett, W. M. (1978) Light hydrocarbons in recent Texas continental shelf and slope sediments. J. Geophys. Res. 83, 4053-4061.

Berner, U. and Faber, E. (1996) Empirical carbon isotope/maturity relationships for gases from algal kerogens and terrigenous organic matter, based on dry, open-system pyrolysis. Org. Geochem. 24, 947-955.

Busch, C. (1995) Untersuchung der Gasgehalte karbonischer Kohlen und Gesteine der Bohrung Kozlu K-20/H, Zonguldak-Becken (NW Türkei). Diplom Thesis, Bergakademie Freiberg (unpublished).

Clayton, C. J., Hay, S. J., Baylis, S. A. and Dipper, B. (1997) Alteration of natural gas during leakage from a North Sea salt diapir field. Mar. Geol. 137, 69-80.

Cui, X., Bustin, R. M. and Dipple, G. (2004) Selective transport of $\mathrm{CO}_{2}, \mathrm{CH}_{4}$, and $\mathrm{N}_{2}$ in coals: insights from modeling of experimental gas adsorption data. Fuel 83, 293-303.

Dai, J., Yang, S., Chen, H. and Shen, X. (2005) Geochemistry and occurrence of gas accumulations in Chinese sedimantary basins. Org. Geochem. 36, 1664-1688.

Derman, A. S. and İ ztan, Y. H. (1997) Results of geochemical analysis of seeps and potential source rocks from northern Turkey and Turkish Black Sea. AAPG Memoir 68, 313-330.

Faiz, M. M., Barclay, S., Saghafi, A., Stalker, L., Wold, M., Esterle, J. and Sherwood, N. (2002) Coal bed methane reservoir characterization-KP-1 and WG-1, PEL-2, Southern Sydney Basin. Report Prepared for Sydney Gas Company, CSIRO Petroleum Confidential Report No. 02-055, July 2002, 220 pp. (unpublished).

Görür, N. and Tüysüz, O. (1997) Petroleum geology of the southern continental margin of the Black Sea. AAPG Memoir 68, 241-254.

Görür, N., Tüysüz, O., Aykol, A., Sakınç, M., Yiğitbaş, E. and Akkök, R. (1993) Cretaceous red pelagic carbonates of northern Turkey: their place in the opening history of the Black Sea. Ecl. Geol. Helv. 86, 819-838.

Gould, K. W., Hargraves, A. J. and Smith, W. J. (1987) Variation in the composition of seam gases issuing from the coal. Australasian Institute of Mining and Metallurgy Bulletin 292, 69-73.

Gürdal, G. (1998) The controlling parameters of gas storage in coals of the Zonguldak basin. Unpublished Ph.D. Thesis, Istanbul Technical University, Istanbul, 237 pp. (in Turkish).

Gürdal, G. and Yalçın, M. N. (1995) An investigation of factors controlling gas adsorption in coals of the Zonguldak Basin, NW Turkey. Organic Geochemistry: Development and Applications to Energy, Climate, Environment and Human History, Selected papers from the 17th International Meeting on Organic Geochemistry, Donostia-San Sebastian, The Basque Country. Spain, 4-8 September 1995, 11041107.

Gürdal, G. and Yalçın, M. N. (2000) Gas adsorption capacity of Carboniferous coals in the Zonguldak basin (NW Turkey) and its controlling factors. Fuel 79, 1913-1924. 
Harput, B. O., Demirel, I. H., Karayiğit, A. I., Aydın, Ö. and Bustin, R. M. (1999) Preliminary hydrocarbon source rock assesment of the paleozoic and mesozoic formations of the Western Black Sea Region of Turkey. Energy Sources 21, 946-956.

Hoşgörmez, H. (1996) Amount and composition of gas within the Carboniferous sequence in the Zonguldak Basin. Unpublished M.Sc. Thesis, University of Istanbul, Institute of Sciences, 91 pp. (in Turkish with English summary).

Hoşgörmez, H., Busch, C., Yalçın, M. N., Mann, U. and Schaefer, R. G. (1997) Hydrocarbon gases in coals and adjacent strata of the Zonguldak Basin, Turkey. Gas Composition, Abstract, European Coal Conference '97, 5-10 May, Izmir-Turkey, 24 pp.

Hoşgörmez, H., Mann, U., Yalçın., M. N. and Schaefer, R. G. (1998) Total yield and composition of hydrocarbon gases in the coal bearing units of the Zonguldak Basin. 12th International Petroleum Congress and Exhibition of Turkey, Proceedings, 320-328.

Hoşgörmez, H., Yalçın, M. N., Cramer, B., Gerling, P., Faber, E., Schaefer, R. G. and Mann, U. (2002) Isotopic and molecular composition of coal-bed gas in the Amasra Region (Zonguldak Basin-western Black Sea). Org. Geochem. 33, 1429-1439.

James, A. T. and Burns, B. (1984) Microbial alteration of subsurface natural gas accumulations. AAPG 67, 1176-1191.

Karayiğit, A. I . (1989) Petrographic features of the Zonguldak and Amasra coals. Unpublished Ph.D. Thesis, Hacettepe University, Ankara, 315 pp. (in Turkish).

Karayiğit, A. İ ., Gayer, R. A. and Demirel, I . H. (1998) Coal and rank and petrography of Upper Carboniferous coal seams in the Amasra coalfield, Turkey. International Journal of Coal Geology 36, 277-294.

Kerey, I. E. (1982) Stratigraphical and sedimentological studies of Upper Carboniferous rocks in Northwestern Turkey. Unpublished Ph.D. Thesis, University of Keele, 238 pp.

Mahieu, K., Visscher, A. D., Vanrolleghem, P. A. and Cleemput, A., V. (2006) Carbon and hydrogen isotope fractination by microbial methane oxidation: Improved determination. Waste Management 26, 389-398.

Mann, U., Hertle, M., Horsfield, B., Radke, M., Schenk, H. J. and Yalçın, M. N. (1995) Petrographical, organic-chemical and petrophysical characterization of Upper Carboniferous coals from well K20/G, Zonguldak Basin, NW Turkey. Zonguldak Basin Research Wells-I: Kozlu K20/G (Yalçın, M. N. and Gürdal, G., eds.), 133-165, Special Publication of TUBITAK, Marmara Research Center.

Orhan, E. and Canca, N. (1989) Geology and coal occurrences of the (Zonguldak I li) Kandilli - Değirmenağzı MTA Report No. 8549 (unpublished).

Pallaser, R. J. (2000) Recognizing biodegradation on gas/oil accumulations through the $\delta^{13} \mathrm{C}$ compositions of gas components. Org. Geochem. 31, 1363-1373.

Robinson, A. G., Rudat, J. H., Banks, C. J. and Wiles, R. L. F. (1996) Petroleum geology of the Black Sea. Marine and Petroleum Geology 13, No. 2, 195-223.

Sassen, R., Roberts, H. H., Carney, R., Milkov, A. V., DeFreitas, D. A., Lanoil, B. and Zhang, C. (2004) Free hydrocarbon gas, gas hydrate and authiogenic minerals in chemosynthetic communities of the northern Gulf of Mexico continental slope: relation to microbial processes. Chem. Geol. 205, 195-217.

Schaefer, R. G., Pooch, H. and Leythaeuser, D. (1984) Automatic headspace gas chromatography of $\mathrm{C}_{1}-\mathrm{C}_{7}$ hydrocarbons in sedimentary rocks. Application in petroleum geochemistry. Chromatographia 19, 377-381

Scott, A. R. (1993) Composition and origin of coal gases from selected basins in the United States. Proceedings of the 1993 International Coalbed Methane Symposium, The University of Alabama, School of Mines and Energy Development 1, 207-222.

Scott, A. R., Kaiser, W. R. and Ayers, W. B. (1994) Thermogenic and secondary biogenic gases, San Juan Basin, Colorado and New Mexico-Implications for coalbed gas producibility. AAPG Bulletin 78, 1186-1209.

Strapoc, D., Schimmelmann, A. and Mastalerz, M. (2006) Carbon isotopic fractination of $\mathrm{CH}_{4}$ and $\mathrm{CO}_{2}$ during canister desorption of coal. Org. Geochem. 37, 152-164.

Thielemann, T., Cramer, B. and Schippers, A. (2004) Coalbed methane in the Ruhr Basin, Germany: a renewable energy resources. Org. Geochem. 35, 1537-1549.

Yalçın, M. N. (1995) Organic geochemical characterization of some Carboniferous coal seams of the Zonguldak Basin (NW Turkey). NATO Advanced Study Institute, Composition, Geochemistry and Conversion of Oil Shales (Snape, C., ed.), NATO ASI Series C 445, 461-476.

Yalçın, M. N. (1997) Role of basin modelling in coalbed methane resource assessment. The 1997 International Coalbed Methane Symposium, Alabama/USA, Proceedings, 357-364.

Yalçın, M. N., Schenk, H. J. and Schaefer, R. G. (1994) Modeling of gas generation in coals of the Zonguldak basin (NW Turkey). International Journal of Coal Geology 25, 195-212.

Yalçın, M. N., Inan, S., Gürdal, G., Mann, U. and Schaefer, R. G. (2002) Carboniferous coals of the Zonguldak Basin (northwest Turkey): Implications for Coalbed Methane Potential. AAPG Bull. 86, 1305-1328.

Yee, D., Seidle, J. P. and Hanson, W. B. (1993) Sorption on coal and measurement of gas content. Hydrocarbons from Coal (Law, B. E. and Rice, D. D., eds.), AAPG Studies in Geology 38, 203-218.

Yergök, F. A., Akman, Ü., Tekin, F., Karabalık, N. N., Akat, U., Armagan, F., Erdoğan, K. and Kaymakçı, H. (1987) Geology of the Western Black Sea-1. MTA Report No. 2818 (unpublished).

Yılmaz, Y., Tüysüz, O., Yiğitbaş, E., Genç, Ş .C. and Şengör, A. M. C. (1997) Geology and tectonic evolution of the Pontides. Regional and Petroleum Geology of the Black Sea and Surrounding Region (Robinson, A. G., ed.), AAPG Memoir 68, 183-226.

Xu, S., Nakai, S., Wakita, H. I., Xu, Y. and Wang, X. (1997) Carbon isotopes of hydrocarbons and carbon dioxide in natural gases in China. Journal of Asian Earth Sci. 15, 89101.

Zou, Y. R., Zhao, C., Wang, Y., Zhao, W., Peng, P. and Shuai, Y. (2006) Characteristics and origin of natural gases in the Kuqa Depression of Tarim Basin, NW China. Org. Geochem. 37, 280-290. 